\title{
ANALISIS KINERJA KEUANGAN PADA KOPERASI PEGAWAI REPUBLIK INDONESIA (KPRI) TRADISI KABUPATEN JEMBER TAHUN BUKU 2013-2017
}

\author{
Devi Wahyuni Lugita ${ }^{1}$, Sutrisno Djaja ${ }^{1}$, Sri Kantun ${ }^{1}$ \\ ${ }^{1}$ Program Studi Pendidikan Ekonomi, Fakultas Keguruan dan Ilmu Pendidikan, Universitas Jember \\ e-mail: devyw196@gmail.com
}

\begin{abstract}
Abstrak
Penelitian ini dilakukan untuk mendeskripsikan kinerja keuangan yang dicapai KPRI Tradisi Kabupaten Jember pada tahun 2013-2017 dan strategi yang dilakukan untuk mencapai kinerja keuangan yang memenuhi standar Peratuan Menteri Negara Koperasi Dan Usaha Kecil Dan Menengah Republik Indonesia No.06/Per/M.KUKM/V/2006. Penelitian ini merupakan penelitian deskriptif kuantitatif. Metode pengumpulan data yang digunakan yaitu dokumen dan wawancara. Metode analisis data yang digunakan yaitu rasio keuangan yang terdiri dari rasio likuiditas, solvabilitas dan rentabilitas. Hasil penelitian menunjukkan bahwa, kinerja keuangan KPRI Tradisi Kabupaten Jember yang diukur dari rasio likuiditas yaitu current ratio pada tahun 2013, 2015 dan 2016 menunjukkan kinerja yang tidak baik, sedangkan pada tahun 2014 dan 2017 menunjukkan kinerja yang cukup baik. Ditinjau dari rasio solvabilitas yaitu debt to asset ratio dan debt to equity ratio pada tahun 2013-2015 menunjukkan kinerja yang cukup baik, sedangkan pada tahun 2016 dan 2017 menunjukkan kinerja yang baik. Ditinjau dari rasio rentabilitas yaitu return on asset pada tahun 2013, 2016 dan 2017 menunjukkan kinerja yang sangat baik, sedangkan pada tahun 2014 menunjukkan kinerja yang baik dan pada tahun 2015 menunjukkan kinerja yang cukup baik. Rasio return on equity pada tahun 2013, 2014 dan 2017 menunjukkan kinerja yang sangat baik, sedangkan pada tahun 2015 menunjukkan kinerja yang cukup baik dan pada tahun 2016 menunjukkan kinerja yang baik. Selanjutnya, berdasarkan rasio net profit margin yaitu pada tahun 2013, 2014, 2016 dan 2017 menunjukkan kinerja keuangan yang sangat baik, sedangkan pada tahun 2015 menunjukkan kinerja yang baik.
\end{abstract}

Kata Kunci: Kinerja Keuangan, Rasio Keuangan, KPRI Tradisi Kabupaten Jember

\section{PENDAHULUAN}

Perkembangan perekonomian yang semakin maju dan persaingan usaha yang semakin ketat menuntut setiap pelaku ekonomi agar dapat menjaga dan meningkatkan usahanya. Koperasi sebagai salah satu pelaku ekonomi dituntut untuk mampu meningkatkan kinerja dan daya saing dengan tetap mempertahankan jati dirinya sebagai badan usaha yang berwatak sosial dengan tujuan utama meningkatkan kesejahteraan anggota pada khususnya dan masyarakat pada umumnya. Keberhasilan koperasi dalam menjalankan usahanya dapat dilihat dari kinerja yang dicapai pada periode tertentu. Kinerja dapat di lihat dari beberapa aspek, salah satunya yaitu kinerja keuangan (financial performance) (Fahmi, 2014:2).

Kinerja keuangan menunjukkan hasil atau prestasi yang dicapai koperasi dalam mengelola atau mendayagunakan sumber kekayaan yang dimiliki untuk membiayai usaha yang dijalankan. Kinerja keuangan dapat diketahui melalui informasi yang disajikan pada laporan keuangan baik perhitungan hasil usaha, neraca, laporan perubahan ekuitas, laporan arus kas dan catatan atas laporan keuangan sebagaimana yang tercantum pada Peraturan Menteri Koperasi dan UKM tentang Pedoman Umum Akuntansi Koperasi Sektor Riil (PerMenKop, 2015:12).

Penilaian terhadap kinerja keuangan dapat diketahui dengan menggunakan suatu alat analisis yaitu rasio keuangan. Rasio keuangan merupakan perbandingan antara satu pos dengan pos lainnya dalam laporan keuangan, sehingga dapat menunjukkan kondisi dan prestasi keuangan yang dicapai oleh perusahaan (Wardiyah, 2017:85). Adapun rasio keuangan yang dapat digunakan yaitu rasio likuiditas, solvabilitas dan rentabilitas.

Rasio likuiditas digunakan untuk mengetahui kemampuan perusahaan dalam memenuhi kewajiban lancarnya secara tepat waktu pada saat jatuh tempo (Fahmi, 2014:59). Rasio ini penting untuk dianalisis, karena ketidakmampuan koperasi dalam membayar kewajibannya dapat mengurangi kepercayaan kreditur dan anggota koperasi serta dapat mengganggu kelancaran usaha yang dijalankan. Berdasarkan Peraturan Menteri Negara 
Koperasi Dan UKM Republik Indonesia No.06/Per/M.KUKM/V/2006 tentang Penilaian Koperasi Berprestasi/Koperasi Award, koperasi dikatakan memiliki kinerja keuangan yang sangat baik, apabila rasio likuiditasnya sebesar 200\%-250\% (PerMenKop, 2006). Semakin tinggi rasio likuiditas menunjukkan semakin mampu perusahaan dalam memenuhi kewajiban lancarnya (Halim, 2015:216). Hal ini dikarenakan koperasi memiliki sejumlah aktiva lancar yang likuid yang sewaktu-waktu dapat digunakan untuk membayar kewajibannya. Sebaliknya, semakin rendah rasio likuiditas menunjukkan semakin rendah kemampuan perusahaan dalam memenuhi kewajiban lancarnya (Halim, 2015:216). Hal ini dikarenakan aktiva lancar yang dimiliki koperasi tidak mencukupi untuk menutupi kewajibannya pada saat jatuh tempo atau aktiva lancar koperasi kurang likuid, sehingga masih perlu menunggu untuk mencairkannya menjadi kas.

Rasio solvabilitas digunakan untuk mengetahui kemampuan perusahaan dalam melunasi seluruh kewajibannya, baik kewajiban jangka pendek maupun jangka panjang (Kasmir, 2016:151). Rasio ini penting untuk dianalisis karena ketidakmampuan koperasi dalam memenuhi kewajibannya dapat mengurangi kepercayaan kreditur sehingga koperasi sulit untuk memperoleh tambahan pinjaman pada periode selanjutnya, selain itu juga dapat mengganggu kelancaran usaha yang dijalankan bahkan dapat menyebabkan resiko kebangkrutan. Rasio solvabilitas dapat diukur dengan menggunakan debt to asset ratio (DAR) dan debt to equity ratio (DER). Koperasi dikatakan memiliki kinerja keuangan yang sangat baik apabila debt to asset ratio $(\mathrm{DAR}) \leq 40 \%$, dan debt to equity ratio (DER) $\leq 70 \%$ (PerMenKop, 2006). Semakin tinggi rasio solvabilitas menunjukkan semakin besar resiko keuangan yang ditanggung perusahaan, karena dikhawatirkan perusahaan tidak mampu untuk memenuhi seluruh kewajibannya (Hery, 2014:163). Hal ini dikarenakan, aset atau modal yang dimiliki koperasi tidak mencukupi untuk menutupi seluruh kewajibannya, baik kewajiban jangka pendek maupun kewajiban jangka panjang.

Rasio rentabilitas digunakan untuk mengetahui kemampuan perusahaan dalam menghasilkan laba dengan menggunakan semua kemampuan dan sumberdaya yang dimiliki baik hasil penjualan, aset maupun modal (Hery, 2014:192). Rasio ini penting untuk dianalisis untuk mengetahui efisiensi dan efektivitas koperasi dalam menjalankan kegiatan operasionalnya, serta meningkatkan nilai koperasi untuk menarik minat anggota baru atau calon investor. Rasio rentabilitas dapat diukur dengan menggunakan rasio return on asset (ROA), return on equity (ROE) dan net profit margin (NPM). Koperasi dikatakan memiliki kinerja keuangan yang sangat baik apabila rasio return on asset $(\mathrm{ROA}) \geq 10 \%$, rasio return on equity (ROE) $\geq 21 \%$ dan rasio net profit margin $(\mathrm{NPM}) \geq 15 \%$ (PerMenKop, 2006). Semakin tinggi rasio rentabilitas menunjukkan semakin besar kemampuan koperasi dalam menghasilkan SHU dan sebaliknya, semakin rendah rasio rentabilitas menunjukkan semakin rendah kemampuan koperasi dalam menghasilkan SHU baik dari aktivitas penjualan, modal maupun aset yang dimiliki.

Berdasarkan observasi awal yang dilakukan di KPRI Tradisi Kabupaten Jember diperoleh informasi bahwa selama 2 (dua) tahun yaitu pada tahun 2014 dan 2015 SHU yang diperoleh koperasi mengalami penurunan yang menunjukkan rendahnya rentabilitas koperasi. Namun, kondisi demikian tidak berlangsung lama, karena koperasi mampu meningkatkan perolehan SHU pada periode selanjutnya. Demikian pula dengan pemenuhan kebutuhan modal koperasi untuk menjalankan usahanya tidak hanya terbatas pada modal sendiri, namun juga berasal dari modal pinjaman baik bank maupun non-bank. Hal ini menyebabkan besarnya hutang koperasi, sehingga koperasi perlu menjaga kinerja keuangannya berkaitan dengan kelancaran pembayaran kewajibannya agar tidak mengganggu kelancaran dan kelangsungan usaha yang dijalankan.

Berdasarkan pemaparan di atas, maka peneliti bermaksud mengadakan penelitian yang bertujuan untuk mendeskripsikan kinerja keuangan yang dicapai KPRI Tradisi Kabupaten Jember pada tahun 2013-2017 dan strategi yang dilakukan untuk mencapai kinerja keuangan yang memenuhi standar Peraturan Menteri Negara Koperasi Dan Usaha Kecil dan Menengah Republik Indonesia No.06/PER/M.KUKM/V/2006.

\section{METODE}

Penelitian ini merupakan penelitian deskriptif kuantitatif. Penentuan lokasi penelitian menggunakan metode purposive area. Jenis dan sumber data yang digunakan dalam penelitian ini yaitu data primer dan data sekunder. Metode pengumpulan data yang digunakan yaitu dokumen dan wawancara. Metode dokumen digunakan untuk memperoleh data mengenai laporan keuangan KPRI Tradisi Kabupaten Jember yang terdiri 
dari neraca dan laporan perhitungan hasil usaha, sedangkan metode wawancara digunakan untuk memperoleh informasi tambahan mengenai kinerja yang dicapai KPRI Tradisi Kabupaten Jember dan strategi untuk mencapai kinerja keuangan tersebut. Metode analisis data yang digunakan yaitu analisis rasio keuangan yang terdiri dari rasio likuiditas, solvabilitas dan rentabilitas.

\section{HASIL DAN PEMBAHASAN}

\section{Hasil Penelitian}

Hasil analisis tingkat kesesuaian antara rasio keuangan KPRI Tradisi Kabupaten Jember dengan standar rasio berdasarkan Peraturan Menteri Negara Koperasi Dan Usaha Kecil Dan Menengah Republik Indonesia No.06/Per/M.KUKM/V/2006 adalah sebagai berikut:

a. Rasio Likuiditas

1. Rasio Lancar (Current Ratio/CR)

Tabel 1. Kesesuaian antara rasio lancar KPRI Tradisi Kabupaten Jember dengan standar rasio Berdasarkan Peraturan Menteri Negara Koperasi Dan UKM

\begin{tabular}{|c|c|c|c|}
\hline Tahun & Current Ratio (CR) & Kriteria & Tingkat Rasio \\
\hline 2013 & $121 \%$ & Tidak Baik & $<125 \%$ atau $>325 \%$ \\
\hline 2014 & $153 \%$ & Cukup Baik & $150 \%-<175 \%$ atau $>275 \%-300 \%$ \\
\hline 2015 & $87 \%$ & Tidak Baik & \multirow{2}{*}{$<125 \%$ atau $>325 \%$} \\
\hline 2016 & $101 \%$ & Tidak Baik & \\
\hline 2017 & $152 \%$ & Cukup Baik & $150 \%-<175 \%$ atau $>275 \%-300 \%$ \\
\hline
\end{tabular}

Sumber: Laporan Keuangan KPRI Tradisi Kabupaten Jember Tahun Buku 2013-2017 yang diolah

b. Rasio Solvabilitas

1. Debt to Asset Ratio (DAR)

Tabel 2. Kesesuaian antara debt to asset ratio KPRI Tradisi Kabupaten Jember dengan standar rasio Berdasarkan Peraturan Menteri Negara Koperasi Dan UKM

\begin{tabular}{cccc}
\hline Tahun & Debt to Asset Ratio (DAR) & Kriteria & Tingkat Rasio \\
\hline 2013 & $53 \%$ & Cukup Baik & \\
2014 & $56 \%$ & Cukup Baik & $>50 \%$ s/d $60 \%$ \\
2015 & $57 \%$ & Cukup Baik & \\
2016 & $46 \%$ & Baik & $>40 \%$ s/d 50\% \\
2017 & $43 \%$ & Baik &
\end{tabular}

Sumber: Laporan Keuangan KPRI Tradisi Kabupaten Jember Tahun Buku 2013-2017 yang diolah

2. Debt to Equity Ratio (DER)

Tabel 3. Kesesuaian antara debt to equity ratio KPRI Tradisi Kabupaten Jember dengan standar rasio berdasarkan Peraturan Menteri Negara Koperasi Dan UKM

\begin{tabular}{lccc}
\hline Tahun & Debt to Equity Ratio (DER) & Kriteria & Tingkat Rasio \\
\hline 2013 & $114 \%$ & Cukup Baik & \\
2014 & $129 \%$ & Cukup Baik & $>100 \%$ s/d 150\% \\
2015 & $135 \%$ & Cukup Baik & \\
2016 & $84 \%$ & Baik & $>70 \%$ s/d 100\% \\
2017 & $76 \%$ & Baik & \\
\hline
\end{tabular}


Sumber: Laporan Keuangan KPRI Tradisi Kabupaten Jember Tahun Buku 2013-2017 yang diolah

\section{c. Rasio Rentabilitas}

1. Return on Asset (ROA)

Tabel 4. Kesesuaian antara rasio return on asset KPRI Tradisi Kabupaten Jember dengan standar rasio Berdasarkan Peraturan Menteri Negara Koperasi Dan UKM

\begin{tabular}{lccc}
\hline Tahun & Return on Asset (ROA) & Kriteria & Tingkat Rasio \\
\hline 2013 & $13 \%$ & Sangat Baik & $\geq 10 \%$ \\
2014 & $9 \%$ & Baik & $7 \%$ s/d $<10 \%$ \\
2015 & $6 \%$ & Cukup Baik & $3 \% \mathrm{~s} / \mathrm{d}<7 \%$ \\
2016 & $11 \%$ & Sangat Baik & $\geq 10 \%$ \\
2017 & $12 \%$ & Sangat Baik & \\
\hline
\end{tabular}

Sumber: Laporan Keuangan KPRI Tradisi Kabupaten Jember Tahun Buku 2013-2017 yang diolah

2. Return on Equity (ROE)

Tabel 5. Kesesuaian antara rasio return on equity KPRI Tradisi Kabupaten Jember dengan standar rasio Berdasarkan Peraturan Menteri Negara Koperasi Dan UKM

\begin{tabular}{lccc}
\hline Tahun & Return on Equity (ROE) & Kriteria & Tingkat Rasio \\
\hline 2013 & $28 \%$ & Sangat Baik & $\geq 21 \%$ \\
2014 & $22 \%$ & Sangat Baik & \\
2015 & $14 \%$ & Cukup Baik & $9 \% \mathrm{~s} / \mathrm{d}<15 \%$ \\
2016 & $20 \%$ & Baik & $15 \% \mathrm{~s} / \mathrm{d}<21 \%$ \\
2017 & $21 \%$ & Sangat Baik & $\geq 21 \%$ \\
\hline
\end{tabular}

Sumber: Laporan Keuangan KPRI Tradisi Kabupaten Jember Tahun Buku 2013-2017 yang diolah

3. Net Profit Margin (NPM)

Tabel 6. Kesesuaian antara rasio net profit margin KPRI Tradisi Kabupaten Jember dengan standar rasio Berdasarkan Peraturan Menteri Negara Koperasi Dan UKM

\begin{tabular}{lccc}
\hline Tahun & Net Profit Margin $(\mathrm{NPM})$ & Kriteria & Tingkat Rasio \\
\hline 2013 & $17 \%$ & Sangat Baik & $\geq 15 \%$ \\
2014 & $15 \%$ & Sangat Baik & $10 \% \mathrm{~s} / \mathrm{d}<15 \%$ \\
2015 & $11 \%$ & Baik & $\geq 15 \%$ \\
2016 & $18 \%$ & Sangat Baik & \\
2017 & $28 \%$ & Sangat Baik & \\
\hline
\end{tabular}

Sumber: Laporan Keuangan KPRI Tradisi Kabupaten Jember Tahun Buku 2013-2017 yang diolah

\section{Pembahasan}

\section{Analisis Kinerja Keuangan KPRI Tradisi Kabupaten Jember Ditinjau dari Rasio Likuiditas}

Kinerja keuangan yang dicapai KPRI tradisi Kabupaten Jember sebagaimana yang disajikan pada tabel 1 menunjukkan bahwa, pada tahun 2013-2017 kinerja koperasi berada dalam rentang kinerja antara cukup baiktidak baik. Hal ini dikarenakan rasio likuiditas koperasi pada tahun 2013-2017 belum memenuhi standar rasio berdasarkan Peraturan Menteri Negara Koperasi dan UKM dengan nilai rasio < 200\%. Kondisi ini menunjukkan rendahnya kemampuan koperasi dalam memenuhi kewajiban lancarnya dari aset lancar yang dimiliki. 
Rendahnya kinerja koperasi dikarenakan adanya unsur aktiva lancar yang kurang likuid atau adanya over investment pada aktiva lancar yaitu piutang baik piutang usaha pada PLN maupun PT CKB atas pinjaman yang diberikan koperasi. Penyebab lainnya yaitu rendahnya hasil usaha dari aktivitas usaha yang dijalankan dan meningkatnya hutang koperasi. Adapun upaya yang dilakukan KPRI Tradisi Kabupaten Jember untuk meningkatkan kinerjanya yaitu dengan memaksimalkan usaha yang dimiliki baik melalui peningkatan pelayanan kepada anggota, menambah usaha baru seperti jasa pelayanan pemesanan tiket online dan mengembangkan usaha PT CKB. Anggota koperasi juga diharapkan berperan aktif dalam menggunakan jasa koperasi, sehingga dapat meningkatkan pendapatan koperasi dan mengurangi pinjaman kepada pihak eksternal.

\section{Analisis Kinerja Keuangan KPRI Tradisi Kabupaten Jember Ditinjau dari Rasio Solvabilitas}

Debt to asset ratio (DAR) KPRI Tradisi Kabupaten Jember sebagaimana yang ditunjukkan pada tabel 2 menunjukkan bahwa, kinerja keuangan koperasi pada tahun 2013-2017 berada pada rentang kinerja antara cukup baik-baik. Hal ini dikarenakan rasio koperasi belum memenuhi standar rasio yang berlaku yaitu $\leq 40 \%$. Rendahnya kinerja keuangan tersebut dikarenakan besarnya hutang koperasi baik kepada pihak bank, non-bank maupun anggota koperasi untuk memenuhi kebutuhan dana sekaligus menunjang kelancaran usaha yang dijalankan. Penyebab lainnya yaitu rendahnya hasil usaha baik pada unit pertokoan, simpan pinjam (USP), jasa usaha/sewa serta adanya dana yang kurang produktif yaitu besarnya dana yang dialokasikan pada persekot operasional atas pengadaan barang dan jasa. Faktor lainnya yaitu berkurangnya nilai investasi saham atas persewaan Honda Freed dikarenakan sudah tidak lagi disewa oleh pihak PLN karena koperasi kalah lelang dengan usaha sejenis lainnya yaitu PT Kallatrans.

Upaya yang dilakukan KPRI Tradisi Kabupaten Jember untuk memperbaiki kinerjanya yaitu dengan meningkatkan aktivitas usaha, sehingga pendapatan dapat ditingkatkan dengan demikian aset koperasi pun meningkat pula. Selain itu, koperasi juga berupaya untuk meningkatkan partisipasi anggota dalam menggunakan jasa koperasi dengan meningkatkan pelayanan baik kepada anggota, masyarakat, maupun mitra kerja. Koperasi juga harus lebih efektif dalam mengelola asetnya, sehingga dapat digunakan secara produktif. Hal ini dimaksudkan agar koperasi lebih mandiri dalam menjalankan usahanya dan dapat mengurangi pinjaman kepada pihak luar.

Debt to equity ratio (DER) KPRI Tradisi Kabupaten Jember pada tahun 2013-2017 sebagaimana yang ditunjukkan pada tabel 3 di atas menunjukkan bahwa, kinerja keuangan koperasi berada pada rentang kinerja antara cukup baik-baik. Hal ini dikarenakan rasio koperasi belum memenuhi standar rasio yaitu $\leq 70 \%$. Rendahnya kinerja tersebut disebabkan karena terbatasnya modal koperasi yang dihimpun dari anggota sedangkan kebutuhan dana cukup besar, sehingga kekurangan modal diatasi dengan melakukan pinjaman kepada pihak luar yaitu bank dan lembaga keuangan non-bank, akibatnya semakin besar beban hutang yang ditanggung koperasi. Penyebab lainnya yaitu rendahnya hasil usaha yang diperoleh koperasi baik karena rendahnya partisipasi anggota, persaingan usaha yang semakin ketat, terbatasnya ruang lingkup kerja koperasi maupun berkurangnya kontrak sewa dari PLN.

Upaya yang dilakukan KPRI Tradisi Kabupaten Jember untuk meningkatkan kinerja keuangannya yaitu meningkatkan modal sendiri dengan menaikkan simpanan pokok dan simpanan wajib yang dibayarkan oleh anggota. Koperasi juga berupaya untuk meningkatkan hasil usaha dengan meningkatkan partisipasi anggota, memaksimalkan usaha yang dimiliki dan lebih efektif dalam mengelola modal yang dimiliki serta berupaya mengurangi pinjaman kepada pihak luar.

\section{Analisis Kinerja Keuangan KPRI Tradisi Kabupaten Jember Ditinjau dari Rasio Rentabilitas}

Kinerja keuangan KPRI Tradisi Kabupaten Jember yang diukur berdasarkan rasio return on asset (ROA) pada tahun 2013-2017 sebagaimana yang disajikan pada tabel 4 di atas menunjukkan bahwa, kinerja koperasi berada pada kondisi antara sangat baik-cukup baik. Keberhasilan kinerja koperasi sebagaimana yang dicapai pada tahun 2013, 2016 dan 2017 disebabkan karena meningkatnya partisipasi anggota, bertambahnya aset koperasi karena adanya pembelian aset baru sekaligus untuk menggantikan aset lama seperti sepeda motor, komputer dan perahu karet, serta meningkatnya pendapatan atas investasi saham koperasi baik pada PT CKB maupun investasi saham Mobil Honda Freed. Faktor lainnya yaitu besarnya penerimaan atas pembayaran 
piutang baik dari anggota maupun PT CKB serta meningkatnya pendapatan koperasi baik pada unit pertokoan, simpan pinjam, sewa perahu karet, komputer serta kemampuan koperasi dalam meminimalkan pengeluaran untuk membiayai usaha yang dijalankan.

Rendahnya kinerja koperasi yaitu pada tahun 2014 dan 2015 disebabkan karena adanya unsur aktiva lancar yang kurang likuid seperti besarnya piutang koperasi dan persekot operasional yang dicadangkan untuk pekerjaan pengadaan barang dan jasa, rendahnya hasil usaha yang diperoleh koperasi seperti pada unit pertokoan, simpan pinjam maupun jasa usaha. Penyebab lainnya yaitu menurunnya investasi saham koperasi, adanya penjualan aset tetap, rendahnya partisipasi anggota dan berkurangnya kontrak kerja dengan PLN. Hal ini sebagaimana ditunjukkan dengan menurunnya SHU koperasi pada tahun 2014 dan 2015.

Upaya yang dilakukan KPRI Tradisi Kabupaten Jember untuk meningkatkan kinerja keuangannya yaitu lebih efektif dalam mengelola aktiva sehingga pendapatan dapat ditingkatkan yang pada akhirnya akan meningkatkan perolehan SHU. Koperasi juga harus berupaya untuk mengoptimalkan dan mengembangkan usaha yang dimiliki maupun usaha PT CKB, meningkatkan pelayanan baik pada anggota, non-anggota maupun mitra kerja serta lebih efisien dalam pengeluaran.

Ditinjau dari rasio return on equity (ROE) seperti yang disajikan pada tabel 5 di atas menunjukkan bahwa, kinerja keuangan yang dicapai koperasi pada tahun 2013-2017 berada pada rentang kinerja antara cukup baik-sangat baik. Keberhasilan kinerja koperasi yaitu pada tahun 2013, 2014 dan 2017 disebabkan karena efektivitas koperasi dalam mengelola modal yang dimiliki untuk menjalankan aktivitas usahanya. Penyebab lainnya yaitu meningkatnya pendapatan koperasi dan efisiensi pengeluaran untuk membiayai usaha yang dijalankan, sehingga SHU yang diperoleh meningkat.

Rendahnya kinerja keuangan yang dicapai koperasi pada tahun 2015 dan 2016 disebabkan karena besarnya modal yang dialokasikan pada PT CKB atas pinjaman yang diberikan koperasi dan piutang usaha kepada PLN atas jasa sewa yang diberikan. Penyebab lainnya yaitu menurunnya pendapatan baik pada unit sewa sepeda motor maupun pengadaan barang dan jasa. Faktor lainnya yaitu terbatasnya modal koperasi, aktivitas usaha yang belum optimal karena rendahnya partisipasi anggota, persaingan usaha yang semakin ketat dan berkurangnya kontrak kerja dengan PLN.

Upaya yang dilakukan KPRI Tradisi Kabupaten Jember untuk meningkatkan kinerjanya yaitu lebih efektif dalam mengelola modal yang dimiliki, meningkatkan modal sendiri dengan menambah besarnya simpanan pokok dan simpanan wajib yang dibayarkan oleh anggota koperasi. Upaya lainnya yaitu dengan meningkatkan partisipasi anggota, lebih efisien dalam pengeluaran, mengoptimalkan usaha yang dimiliki dan berupaya membuka usaha baru serta memperluas jaringan usaha PT CKB untuk meningkatkan hasil usaha koperasi

Ditinjau dari rasio net profit margin (NPM) seperti yang disajikan pada tabel 6 di atas menunjukkan bahwa, kinerja keuangan yang dicapai koperasi pada tahun 2013-2017 berada pada rentang kinerja antara baiksangat baik. Keberhasilan yang dicapai koperasi dikarenakan meningkatnya omzet penjualan baik pada unit pertokoan, jasa usaha/sewa, pendapatan deviden atas saham koperasi pada PT CKB dan efisiensi pengeluaran atau biaya yang dikeluarkan koperasi dalam menjalankan aktivitas usahanya. Faktor lainnya yaitu meningkatnya penerimaan atas pembayaran angsuran pinjaman baik anggota, non-anggota maupun mitra kerja koperasi.

Menurunnya kinerja koperasi yaitu pada tahun 2015 disebabkan karena proporsi yang tidak menguntungkan, dimana penurunan penjualan lebih besar dibandingkan dengan menurunnya biaya. Menurunnya penjualan disebabkan karena menurunnya omzet penjualan terutama pada unit sewa mobil karena berkurangnya sewa kontrak dari PLN dan pendapatan atas pengadaan barang dan jasa. Berubahnya sistem pencatatan keuangan koperasi dari accrual basic menjadi cash basic, sehingga pendapatan deviden pada tahun 2015 tidak diakui dan baru diakui pada tahun 2016. Hal ini menyebabkan SHU yang diperoleh koperasi menurun dengan penurunan yang lebih besar dibandingkan pada tahun 2014. Upaya yang dilakukan KPRI Tradisi Kabupaten Jember untuk meningkatkan kinerjanya yaitu dengan meningkatkan volume penjualan melalui upaya memaksimalkan, mengembangkan dan menambah usaha koperasi, seperti jasa pemesanan tiket on line serta usaha PT CKB. Upaya lainnya yaitu dengan meminimalkan biaya yang dikeluarkan untuk membiayai usaha yang dijalankan. 


\section{PENUTUP}

Berdasarkan hasil penelitian dan pembahasan mengenai kinerja keuangan pada Koperasi Pegawai Republik Indonesia (KPRI) Tradisi Kabupaten Jember dapat disimpulkan bahwa, kinerja keuangan koperasi yang diukur berdasarkan rasio likuiditas yaitu pada tahun 2013-2017 berada dalam kinerja antara tidak baikcukup baik. Rasio solvabilitas yang diukur dengan debt to asset ratio (DAR) dan debt to equity ratio (DER) pada tahun 2013-2015 menunjukkan kinerja yang cukup baik, sedangkan pada tahun 2016-2017 kinerja keuangan koperasi mengalami peningkatan yaitu dalam kondisi baik. Ditinjau dari rasio rentabilitas yaitu return on asset (ROA) dan return on equity (ROE) pada tahun 2013-2017 menunjukkan kinerja keuangan dalam kondisi antara sangat baik-cukup baik. Rasio net profit margin (NPM) yaitu pada tahun 2013-2017 menunjukkan kinerja yang sangat baik, kecuali pada tahun 2015 kinerja yang dicapai koperasi dalam kondisi baik.

Berdasarkan kesimpulan di atas, maka saran yang dapat penulis sampaikan yaitu koperasi harus lebih efektif dalam mengelola aktiva dan dana yang dimiliki, mengembangkan unit usaha yang dimiliki dan berupaya menambah unit usaha baru, meningkatkan modal sendiri dan mengembangkan jaringan usaha koperasi.

\section{DAFTAR PUSTAKA}

Fahmi, I. 2014. Analisis Kinerja Keuangan. Bandung: Alfabeta

Halim, A. 2015. Manajemen Keuangan Bisnis Konsep dan Aplikaisnya. Jakarta: Mitra Wacana Media

Hery. 2014. Analisis Kinerja Manajemen. Jakarta: PT Grasindo

Kasmir. 2016. Analisis Laporan Keuangan. Jakarta: Rajawali Press

Peraturan Menteri Negara Koperasi Dan Usaha Kecil Dan Menengah Republik Indonesia Nomor 06/Per/M.KUKM/V/2006. Pedoman Penilaian Koperasi Berprestasi/Koperasi Award. 1 Mei 2006. Jakarta

Peraturan Menteri Koperasi Dan Usaha Kecil Dan Menengah Republik Indonesia Nomor 12/Per/M.KUKM/IX/2015. Pedoman Umum Akuntansi Koperasi Sektor Riil. 23 September 2015. Jakarta

Wardiyah, L.M. 2017. Analisis Laporan Keuangan. Bandung: CV Pustaka Setia 